\title{
As Clear as MUD: Characteristics, Objectives, and Strategies of the Opposition in Bolivarian Venezuela
}

Barry Cannon

\begin{abstract}
Since President Hugo Chávez was first elected in 1998, the Venezuelan opposition seems to have alternated between institutional and extra-institutional power strategies at different junctures. To help explain this pattern, this article constructs a novel theoretical framework from critical readings of both general theory and accounts of the Venezuelan opposition. It proposes that the strategies should be viewed as dialectical rather than discrete. On this basis, it finds that while the Venezuelan opposition has undergone important changes toward institutionalization in its composition, discursive emphasis, and strategic direction, close readings of opposition texts, interviews with opposition actors, and observations of street demonstrations all reveal continuity with previous rupturist and extra-institutional tendencies. Both strategies therefore must be considered to achieve a fuller, more comprehensive vision of the Venezuelan opposition; this conclusion has important theoretical implications for the study of opposition in the wider region.
\end{abstract}

Crom the time he assumed power in February 1999, President Hugo Chávez of Venezuela led a breathtaking process of change that generated huge academic and media interest in the oil-rich country and its president. Yet very little has been written about the Venezuelan opposition, despite many high-profile attempts to dislodge Chávez from power, including a coup in April 2002, a debilitating oil strike in late 2002 and early 2003, a recall referendum against Chávez's mandate in 2004, and an electoral boycott in 2005. This is surprising, considering the high level of interest in Venezuela and the possible instructive potential of the case for theory on opposition studies in general, particularly in the current Latin American context.

It is notable that after these high-profile attempts to overthrow the Chávez government, the Venezuelan opposition seemed to abandon such confrontational strategies. Instead, it embarked on a process of "partidization" through the MUD (Mesa de Unidad Democrática, Democratic Unity Coalition), featuring a return to predominance of politics and political parties, a privileging of electoralism, and a unification of policy platforms and electoral strategies. This strategy has resulted in an electoral momentum in favor of the opposition despite important losses, not least

Barry Cannon is a lecturer in politics in the Department of Sociology at Maynooth University, Ireland. barry.cannon@nuim.ie 
the October 7, 2012 presidential elections against the ailing president. Nevertheless, the premature death of President Chávez on March 5, 2013 and the wafer-thin opposition loss in the ensuing April 15 "special" elections to Nicolás Maduro, Chávez's successor, seem to have bolstered that momentum. On the other hand, extra-institutionalist strategies also have re-emerged, partly resulting from these more recent electoral losses. All this suggests the need for greater urgency to reexamine opposition strategies in the light of such momentous events.

This article seeks to provide that reexamination by reviewing these important changes in opposition strategies and seeking explanations for them. It identifies changes in three key areas with respect to the Venezuelan opposition: its composition, with an increased emphasis on its political over its social constituent groups; its discursive emphasis, with a greater acceptance of state involvement in the oil industry and in social provision; and its strategic direction, with a greater emphasis on the parliamentary over extraparliamentary tactics. The article also asks if these changes will remain permanent or could be subject to further modification, arguing that while the current emphasis may be on constitutionalism, confrontation continues to remain a vital and live opposition strategic resource. Overall, it is argued that the Venezuelan case has important implications for theoretical approaches to the study of opposition, as both institutional and noninstitutional forms of opposition are recurring and often concurrent strategies in the Latin American region; in specific countries, such as Bolivia, Argentina, and Chile; and indeed beyond.

The article will argue this case in five main parts. First, it will briefly review some examples of theoretical literature on opposition, in particular Blondel 1997; Norton 2008; Zariski 1986; and Brack and Weinblum 2009. Here it is argued that a broader focus is needed that would give equal weight to social and extraparliamentary elements and strategies of opposition. Second, it will examine some of the better-known literature on the Venezuelan opposition, specifically Corrales and Penfold 2007; Domínguez 2011; and García-Guadilla 2005, seeking to build a picture of the three main aspects identified above and illustrating how the different analytical approaches are present in each but need to be given equal prominence to provide a fuller, more comprehensive picture of opposition in Venezuela.

Third, this study will provide an account of the opposition's turn to electoralism, supported by qualitative data culled from a close reading of the principal opposition policy text, the "Guidelines for a Government of National Unity Program (2013-2019)" (Lineamientos para el Programa de Gobierno de Unidad Nacional, 2013-2019), published in January 2012 (MUD 2012), and from a series of interviews with elected opposition representatives and representatives from oppositionlinked civil society organizations. Fourth, it will provide further data on the continuation of extra-institutional strategies, concentrating specifically on student-led demonstrations from the 2007 period on and more recent disturbances in the aftermath of the close 2013 presidential elections. The last section provides some tentative conclusions as to the composition, discursive emphasis, and strategies of the Venezuelan opposition, and offers Zariski's theories on legitimacy as a possible theoretical framework for explaining the variance in strategies. Furthermore, it under- 
lines the importance of the Venezuelan case for the study of opposition in a number of other polities in the region.

\section{OPPOSITION IN THEORY}

At the heart of opposition studies lies a conflict in interpretative approaches; namely, between narrower institutionalist analyses and broader, more flexible approaches taking extra-institutional factors into account. Blondel (1997), for example, argues that the types of opposition that emerge in a given polity are conditioned by external structures over internal factors, with a pronounced emphasis on the type of ruling regime-whether it is authoritarian, liberal, or mixed-and on institutions, but also on social factors, such as socioeconomic inequality and cultural and ethnic differentiation. Norton (2008), meanwhile, emphasizes the importance of the institutionalized party opposition but also highlights a possible multivariate opposition, which goes beyond the main opposition party and beyond the legislature. In both these cases, therefore, there is recognition of both institutional and noninstitutional variables in the study of opposition. Yet in the end they share with much of the literature on opposition a tendency to divide it into parliamentary and extraparliamentary elements, privileging the former and their quest for power as the ultimate object of study (Brack and Weinblum 2011).

Zariski (1986) develops these themes more helpfully by concentrating on the concept of legitimacy, which he defines broadly as the maintaining of the opposition's social and organizational base while it seeks to convince key power actors and a majority of voters of its "fitness to govern" (Zariski 1986, 30). Following Tarrow (1982), legitimacy here is "endogenous" and "exogenous," involving two "games," the "internal" and the "external," respectively (that is, internal and external to the opposition, not to the polity in question). The first "internal game" refers to party members, activists, and habitual followers, and here the object is to "convince them that [the party] still remains true to established goals and traditions" (Zariski 1986, 31). The second "external game" refers to groups external to the opposition, such as individual voters, major interest groups, other political parties, and relevant foreign powers, with an aim of convincing these of the opposition's "fitness to govern." That is, that the opposition would not "somehow endanger the fundamental interests of the society and perhaps jeopardize the survival of the political system itself" (Zariski 1986, 30). His conception could therefore be set out as shown in table 1 .

A major issue identified here is the strong possibility of conflict arising between both these "games" (Zariski 1986), especially in "the absence of tangible payoffs from the external game" (Zariski 1986, 42); that is, winning national power. In other words, Zariski highlights the possibility of conflict over strategy arising between the institutionalized and noninstitutionalized opposition. Zariski's conception is therefore more comprehensive in its approach.

Yet Zariski's case studies (European left parties during the Cold War) are somewhat limiting in a number of important respects. First, they do not include the possibility that opposition groups could be further to the right of the governing party, 
Table 1. Zariski's Opposition Legitimacy Matrix

\begin{tabular}{lll}
\hline \hline & Internal Game & External Game \\
\hline Actors & $\begin{array}{l}\text { Party members, activists, and } \\
\text { habitual followers }\end{array}$ & $\begin{array}{l}\text { Individual voters, major interest } \\
\text { groups, other political parties, } \\
\text { and relevant foreign powers }\end{array}$ \\
Objectives & $\begin{array}{l}\text { "[C] } \text { onvince them that [the party }] \\
\text { still remains true to established } \\
\text { goals and traditions" }\end{array}$ & $\begin{array}{l}\text { Convince these of the } \\
\text { opposition's "fitness to govern" }\end{array}$ \\
\hline \hline
\end{tabular}

Source: Zariski 1986, author's elaboration

bringing into play different sets of exogenous and endogenous constituencies for opposition parties. Hence, different interest groups and different sets of foreign powers could be part of the endogenous or exogenous group-that is, supportive of the opposition ("endogenous") or wary of the opposition and supportive of the government and the existing institutionality ("exogenous")—-depending on their respective policy positions. Second, legitimacy is a currency that needs constant maintenance, whether in office or out, meaning that both opposition and government are constantly seeking to maintain and bolster their legitimacy in the eyes of their supporters and the wider electorate. Hence, there is a dialectic between both legitimacyseeking strategies, which could influence and modify their respective contents.

Nevertheless, Zariski's conceptual framework brings new tools for analysis of opposition, widening the scope of inquiry beyond the parliamentary. It points to a need for a hybrid approach that gives equal consideration to both institutional and noninstitutional factors (Brack and Weinblum 2011). This article attempts to do this, using the Venezuelan case to illustrate vividly the struggle between both these tendencies - the institutional and the need for a broader conception of opposition, one that includes and goes beyond the institutional.

\section{OPPOSITION IN VENEZUELA in Theoretical Perspective}

Three main academic considerations of the Venezuelan opposition, Corrales and Penfold 2007, Domínguez 2011, and García-Guadilla 2005, can illustrate how the Venezuelan case demonstrates the need for a more flexible, combined approach to opposition studies. Each of these studies arguably emphasizes different aspects of the approaches outlined above.

To begin with, Corrales and Penfold (2007) are more orthodox in their approach, privileging institutions in their account by presenting these as the norm by which others are measured. It is President Chávez's undermining and mistreatment of institutions that is deleterious to the Venezuelan "body politic" as a whole, befuddling the opposition in its job by constantly moving the goalposts. Hence the 
norm by which the Bolivarian regime is measured is liberal democracy itself, and it is found wanting in the extreme.

Domínguez (2011), on the other hand, emphasizes structural power as the key area where battle lines are drawn; institutions are barely mentioned. Furthermore, it is the opposition, rather than the Chávez government, that has acted undemocratically, and it is capable of doing so again, as opposition strategies are unified in purpose and intent, not ad hoc responses to rule bending by the incumbent, as Corrales and Penfold (2007) contend.

García-Guadilla (2005), by contrast, emphasizes the social realm in terms of civil society's role as both victim and progenitor of such political and ideological polarization. In her account, the increased social differentiation that developed during the preceding Punto Fijo period has consolidated into mutually exclusive political positions, neither of which seems capable of creating a unifying alternative.

Despite these differences, taken as a whole, these studies point to the broader approach to opposition advocated above. First, all three agree that the sociopolitical character of the current Bolivarian state goes beyond liberal democracy, although there is disagreement over whether this is predominantly positive or negative for Venezuela and its people. Second, there is recognition, more prominent in Domínguez 2011 and García Guadilla 2005 than in Corrales and Penfold 2007, of the breadth of actors involved in the Venezuelan opposition and the variety of strategies it uses. In sum, there is agreement on the multivariate nature of the Venezuelan opposition, drawn from a variety of organizational backgrounds and locked into a protracted battle with a government and state system it views as inimical to its interests and objectives.

Those objectives are seen, implicitly or explicitly, as fundamentally to construct, or, as the opposition would argue, restore, a liberal-democratic politico-institutional regime (liberty) and a market-based socioeconomic regime (property rights). Both of these are, in turn, considered essential to protect the interests of the social and corporate groups in the opposition and hence to restore Venezuela to its "natural" economic, social, and political trajectory. Therefore, taken overall, opposition studies in Venezuela recognize both the institutional elements and the wider ideological and social context and manifestations of the opposition, albeit with different degrees of emphasis. This points to a wider framework of analysis that takes into account both institutionalized and noninstitutionalized aspects of opposition to provide a more comprehensive and complete understanding of opposition politics in Venezuela. 


\section{THE SEARCH FOR UNITY: INSTITUTIONAL STRATEGIES}

When Chávez came to power in 1999, some opposition groups initially cooperated with the new government, responding to its perceived moderation (Cannon 2009, 80). This changed, however, when the new National Assembly granted the president emergency powers, allowing him to pass 49 laws on major issues, including education, land reform, oil, and fishing (Cannon 2009, 80). This signaled the beginning of a new, more radical phase in government policy (Ellner 2008, 112), which led to a bitter and pronounced confrontational stage between opposition and government that persisted until 2006 (see Domínguez 2011).

\section{The Search for Political Unity}

Both these latter stages were characterized by a search for unity among the opposition, the first largely civil society-based (García-Guadilla 2005), the second and current strategy mostly party-based. The first strategy was marked by the establishment of the Democratic Coordinator (Coordinadora Democrática, CD), a heterogeneous grouping of political parties, NGOs, the business association Fedecámaras, the trade union confederation, and the CTV (Venezuelan Workers' Confederation, Confederación de Trabajadores de Venezuela), with Catholic Church and media support. Lasting from October 2002 to about August 2004, its disappearance was attributed by interviewees to its very heterogeneity. Nevertheless, according to one interviewee, it laid the basis for the emergence of later unity strategies, as it created basic structures and decisions on which the MUD coalition could build (Abdul 2012). Nor did it mean the end of civil society involvement in opposition politics, as the ample participation in policy formation with the current MUD demonstrates (see MUD 2012, appendix 2).

The second phase in opposition unity began to gain momentum when the opposition presidential candidate, Manuel Rosales, officially accepted defeat in the 2006 presidential elections, "the first time an opposition politician had recognized a Chavista victory" (Domínguez 2011, 125). In this phase, politics and political parties would dominate, although extrapolitical tactics would continue to play an important part in opposition strategy. This move to a more institutionalist, partybased stage consisted of three elements reached through various agreements. First, moves to create a formal, unified electoral vehicle were made in January 2008. These culminated in the formation of the MUD, with about 30 parties becoming affiliated eventually, but with a variety of ideological and programmatic positions and regional spreads (MUD 2008).

Second, a unified candidate system was adopted, in an attempt to end tendencies to diffusion, initially through party pacts and then through election primaries. Third, a unified discourse began to take shape, expressed most notably in the Guidelines for the Government of National Unity Program, 2013-19 (MUD 2012). ${ }^{1}$ An important feature of this document is the opposition's acceptance of key elements 
of the present system, including the 1999 Constitution, the maintenance of state oil company PDVSA in state hands, and the priority of social policy.

These moves in the direction of unity and constitutionalism initially resulted in a run of three electoral successes, two national and one internal. In local elections in November 2008, the opposition won six of the most important states in the country, in terms both of population and wealth. In legislative elections in September 2010 , it won only 1 percent fewer votes (47.7 percent) than the governing party, the United Socialist Party of Venezuela (PSUV) (48.9 percent), an unprecedented result for the opposition since Chávez took office. This win, however, translated into a PSUV majority in the Assembly of 98 seats to the opposition's 67, due to Venezuela's parallel electoral system. ${ }^{2}$ Nevertheless, it deprived the government of the two-thirds majority needed to select officials with constitutional powers, such as the Human Rights Ombudsman (Defensor del Pueblo) or members of the Supreme Electoral Tribunal (TSE), and to grant the president enabling power to enact extraordinary legislation, an important power that the government had already used to great effect up to then. ${ }^{3}$

Finally, what was hailed as an "exemplary" primary process on February 12, 2012 to choose the opposition candidate for the October 7 presidential elections resulted in an overwhelming triumph for the 39-year-old candidate of the Justice First (Primero Justicia) Party, Henrique Capriles Radonski, governor of Miranda State. ${ }^{4}$

Thus the Venezuelan opposition seems to have moved from confrontational to largely electoral power strategies, based on a search for political unity. The move has resulted in relative success, bringing the opposition increasing electoral strength despite its overall failure to win power at the national level. This tendency to a unified electoral strategy is reinforced by parallel attempts at unity in discourse and policy level.

\section{The Search for Programmatic Unity}

The opposition's detailed attempts at policy unification offer three main policy strategies: economic "reactivation," democratic "reconstruction," and social "recomposition." This section will examine these in turn, using relevant statements from both the Lineamientos (noting clause numbers in parentheses) and interviews with key opposition political and social representatives. ${ }^{5}$ The aim of this section is to show how the search for legitimacy by the opposition can explain apparent moves toward government positions in some of these areas, particularly with regard to oil and social policy. Nevertheless, it also shows that such moves are sometimes more discursive than real, as changes envisaged even in these areas would still represent profound moves away from the current socioeconomic structure, with its emphasis on state intervention, toward a market-dominated one. 


\section{Democratic "Reconstruction"}

A central discourse emerging from the opposition is the need to "reconstruct" the country's institutions, seen as dominated by Chávez and used for his own personal, party political, and ideological ends. Such reconstruction is necessary to ensure personal and social liberty and because the "possibility of success for the economic system critically depends on the solidity of institutions" (Lineamientos 304).

The overall aim of democratic "reconstruction" has five main objectives: adopt fully the terms of the 1999 Constitution, most notably ensuring that human rights and constitutional guarantees are respected; "strengthen and promote" spaces for consensus building, participation, and social dialogue, and guarantee access to justice; invigorate and remodel the public powers, including promoting the independence and autonomy of each branch of government at the national, state, and municipal levels; restore powers to states and municipalities taken from them under the present government; and undertake the professionalization and modernization of state bureaucracies in order to "adapt them to the needs of a modern State" (1314). Hence, there are elements of continuity with existing policy, in the acceptance of the 1999 Bolivarian Constitution in particular-a major departure from previous rupturist discourses - and in the references to participation and social dialogue. Yet there are also elements of rupture, particularly the emphasis on decentralization of powers to states and municipalities. What sort of measures will be implemented to achieve these objectives, and what impact may they have?

The objective of strengthening the constitution will be achieved by diluting the power of the executive and dispersing it into revived institutions from the Punto Fijo era that have been neglected since Chávez came to power, such as the Federal Council of State (57). ${ }^{6}$ The vice president's powers will be strengthened (60-62), with a recommendation that he or she participate, U.S.-style, as a cocandidate in presidential elections (62). The National Assembly's powers of inspection and control will also be strengthened (63-66), and limits to the amount of terms for public representatives, abolished by the present government in 2009, will be introduced once again (67-68).

The public service will be reoriented to support the "country's economic and social development" (151). This will entail a thorough review of all operations and outcomes, "identifying overlaps" and other inefficiencies (207); possible changes in staffing levels (211), probably downward, as current staffing levels are identified as too high (152-55); and led by "people with democratic values" committed to such a program (239). The justice system (91-95) and the armed forces (96-107) will also be reformed, the former strengthened and professionalized and the latter subjected to civilian control.

A further key element in this drive for efficiency is to decentralize powers to the regional and municipal levels, as the experience of decentralization of services to those levels in the immediate pre-Chávez period (1990-98) is regarded as having been more successful than the "centralist disaster" of the current government (16678). As a result, regional and municipal control over areas such as health, education, 
policing, housing, urban planning, ports, airports, and social programs will be reinstated or strengthened, receiving increased resources to manage these services. Participative agencies developed during the Chávez era, such as communal councils, seen in their present incarnation as "supervised participation" (participación tutelada, 200), will be "stripped of all ideological-party bias" and of any "public functions which are contrary" to their original purpose (75) and linked more directly to regional and municipal governments (76) rather than to the president's office, as they are now.

To sum up, the "reconstruction" of institutions is synonymous with the "reconstruction" of the country's democracy, envisaged in this case as classic liberal democracy, confirming García-Guadilla's identification of that system as the main standard of the opposition. The aim here is, above all, to restrict the executive, to transform the Venezuelan state into what María Corina Machado envisages as "a strong state but restricted to a series of functions" (Machado 2012), and to bring it closer to "a more pragmatic consideration of the state-citizen [relation] that is not on a left-right axis" (Machado 2012).

\section{Economic "Reactivation"}

Economically, MUD policies aim to develop what the opposition refers to as a "productive society" (Lineamientos 43), as opposed to the current rentier society, whereby, in the words of Julio Borges, "a person does not live from her own work but from rent" (Borges 2012). To achieve this change from rentism to "productivism," the opposition seeks, on the one hand, to refrain from being "ideologically pure or closed" but insists, on the other hand, that policy must be fundamentally grounded in "the preservation and guarantee of private property, of economic liberty and of private initiative" (43).

Opposition economic policy has five main objectives: "protect the country from oil price volatility, grow and diversify its production, generate new businesses and productive employment, reach a one-digit inflation level, and combat poverty in a sustainable manner" (364). Toward these ends a wide range of proposals are made in the Lineamientos, some of them with possibly far-reaching implications, including

- The revision of existing bilateral and multilateral trade treaties (368), including evaluating the "positive" aspects of free trade treaties (1232)

- Reengaging with multilateral lending agencies (403)

- Restoring the "autonomy" of the Central Bank of Venezuela (407-9)

- Returning expropriated businesses and lands to their original owners (427)

- Facilitating greater involvement of the private sector in currently state-owned enterprises, especially electricity (424)

- Removing the state from most of the agribusiness sector (424)

- Prohibiting - by decree—any form of national executive intervention in private property (590) 
- Designing a massive public education campaign to explain such government actions (599), including inserting material into national primary and secondary curriculums that explains the "connection between property, economic progress, political liberty and social development" (612)

- Raising water rates to allow water provision to be economically sustainable (1001)

Despite, or perhaps because of, the breadth and depth of such changes, a cautious approach to their introduction will be adopted, as "such a path can only be followed gradually, having as its first objective the commitment to protect the most vulnerable at every moment" (364).

To achieve these objectives, one of the first tasks is to reduce the size of the state, which, according to Julio Borges, is "absolutely enormous, oil-dominated, bureaucratic, and which has gone about co-opting people's lives and consciences" (Borges 2012). This task is envisaged principally as a realignment of the central relationship between the state and the national oil company, PDVSA. Although there are different proposals to achieve this, all have three essential aims: "the reduction of the ability of the Executive to capture and use oil resources ... the need to create mechanisms to separate production and spending decisions and the need to situate this restructuring of PDVSA within a larger plan aimed at developing the hydrocarbons industry as a first priority" (482).

To achieve these objectives, measures will be directed at "restructuring PDVSA as a part of the hydrocarbons industry, increasing private participation in the industry and creating a new regulating entity independent of the National Executive" (497). Some measures contemplated include revising all current laws pertaining to the oil industry and the reduction of current regulations on state-private sector balance in oil ventures (514); recruiting new personnel, including those who lost their jobs after the 2002-3 oil strike (497); increasing oil production (484), as opposed to current policy restricting it; limiting PDVSA's tax and social contributions (497); and imposing a "gradual rise in oil prices" domestically (518), a move that previously sparked the Caracazo uprising in 1989 (see Coronil and Skurski 1991).

Thus, while PDVSA may stay in state hands, it would be unrecognizable from its present configuration if the opposition were to achieve power, as it would be less under direct political control, would have much greater levels of private sector involvement, would itself act much more as a private company, albeit state-owned, and would cease to exercise or at least reduce substantially its many current social and welfare roles.

Furthermore, the document is not entirely clear with regard to privatizing other nationalized industries. The Lineamientos state that there is a need to "establish the preeminence of private ownership over state ownership, especially in those sectors where the historical evidence shows greater efficiency" (587). Yet it is unclear exactly what that language means, and in interviews for this study, prominent opposition politicians expressed differing views. Ismael García of the social-democratic PODEMOS categorically states, for example, that oil, electricity, and water "must 
be in the hands of government and the state, obviously for strategic reasons. They cannot be privatized" (2012). On the other hand, María Corina Machado, an independent politician of a more liberal outlook, argues that "strategic sectors don't exist; they are businesses, period" (2012), while Julio Borges of the center-right First Justice Party seems to support Machado's position, excepting, however, the oil industry, which, he says, "seems to me strategic, but [which] we could open up to Venezuelans, to the money which is in other countries to be invested in this country" (2012).

Opposition economic policy therefore could be characterized by two main elements. First, it gives preeminence to the private over the public-envisaging a pivotal role for private property as the principal, if not the only, means to economic progress. This could mean privatizations of huge swaths of the economy that the four successive Chávez-led governments have nationalized, areas such as telecommunications, banking, and food distribution. Moreover, it could mean privatization, or at least greater private sector involvement in, other key areas of the economy, such as the electricity and water services, which could have a profound impact on how those services are delivered and priced.

Second, there is a more nuanced vision of the role of the state oil company, PDVSA, from previous rupturist discourses advocating its total privatization. Opposition policy accepts its present condition as a state-owned company but would remove it from immediate governmental control, open it to wider private sector involvement, and subject it to national and global competitive pressures. Therefore, we could term opposition economic policy as gradual pragmatic productivism, and as such it would represent a major reversal of current government policy, despite some important continuities.

\section{Social "Recomposition"}

The overall aim of opposition social policy, which is seen as complimentary to the economic policy, is to create "access to dignified and well-paid jobs, a quality education in a competitive world, and a highly efficient public health and social security system, among others" (Lineamientos 43). Again in a notably continuist vein, the Chávez government's Social Missions will be preserved, albeit stripped of their supposed clientelistic, demagogic, and ideologically discriminatory uses (42). Crucial to this policy will be their removal from direct executive control, placing them in the power of the respective ministries (390) and ensuring that the "benefits of these [programs] reach the target population" (390).

Furthermore, responsibility for the Into the Neighborhood Health Missions (Barrio Adentro I and II) will be decentralized to the state level (879) as part of a general decentralization policy, which will also see responsibility for schools (860) and hospitals returned to regional state and municipal hands, accompanied by a "revision" of agreements with Cuba on provision of personnel for these programs (882). Moreover, private sector involvement in social provision will be encouraged to help manage "budget restrictions" (370). In education, this will specifically involve the 
maintenance of school installations (822); it will figure in an unspecified manner in health provision (882), as well as private provision of "goods and services of urgent necessity" in both these areas (369). Private provision will also be structured into a new pension system (900).

Important, too, are plans for citizen security, as crime and violence have been major points of public criticism of the government by the opposition (675-96). These critiques have alleged that the government has not made these issues a political priority (696). The opposition seeks to rectify this by setting up a new permanent campaign against crime, led by the president (697), under the auspices of a new coordinating National System of Citizen Security (698) and with the support of new Neighborhood Security Committees (700) composed of "natural community leaders" (740). An unspecified policy of "depoliticization" will be pursued in relevant government ministries (752), in the justice system, the national police (713), and the national criminal and forensic police (CICPC) (755). Additionally, all international treaties signed and ratified by the state will be "strictly applied," with special emphasis on "systemic crimes"; namely, "drug trafficking, terrorism and its financing, organized crime, corruption and money laundering" (701).

Opposition social policy therefore has several notable characteristics. It includes a commitment to enact a strong, vigorous social policy to combat poverty. This, however, is conceived less as universal in the widest sense and more as targeted at those seen as "most in need ... because the state cannot maintain all of society" (García 2012). It is also ultimately oriented toward creating opportunities to achieve individual autonomy, as Borges vividly illustrates in this comment on the purpose of the Missions.

Suppose that you fall in the river and you don't know how to swim and you are drowning. The Missions are the life preservers, which are launched so that you can float and save yourself; the difference between the government and us is that we are clear that the final aim is to get you out of the river. For the government, the ultimate aim is that you stay floating in the river, dependent on the government. (Borges 2012)

Indeed, Borges goes further, arguing that the ultimate aim of social policy is the end of such social supports, which will be achieved through the "productive" economic policies outlined above.

In other words, the best social policy is that the country does not need social policy. That it goes beyond that level of need. How is that achieved? With the other stage of productivity, investment, diversification of the economy. (Borges 2012)

In addition, while this task is seen to be primarily that of the state, wide scope is left open for the private sector in all areas of social policy, both directly and indirectly, which seems to be linked to a policy of decentralization of these services to the state and municipal levels. Social, police, and justice services are characterized by an emphasis on "quality" and "efficiency" rather than on supposed partisan criteria, and policies of "depoliticization" are signaled in all these areas. Chief among the tar- 
gets for such a policy will be the existing Mission programs installed by the Chávez government, which, while continued, will nonetheless be tied to other services, "professionalized," and integrated into the pertinent ministries and their existing service provision.

Therefore, one could summarize opposition social policy as social market policy, in the sense that social services are provided according to people's participation in the labor market. This approach is viewed as the ideal path to achieve individual autonomy, which in turn is equated, in the final analysis, with an absence of the state from social provision. Moreover, while some level of continuity is suggested with an emphasis on poverty and assurances that some of the more important Missions will be maintained, this may be more in appearance than in substance, as suggested here by a representative from a liberal think tank.

The opposition is going to have to look again at everything to do with the Missions and work on that basis and most probably leave the name of Mission because there are people who are very frightened that they will lose their scholarship. (Guijarro 2012) ${ }^{7}$

\section{The SEARCH For Rupture: EXTRA-INSTITUTIONAL STRATEgIES}

The period 2001-6 was marked by an extra-institutional strategy on the part of the Venezuelan opposition. This strategy had its high points in the 2002 attempted coup and the 2002-3 oil strike. There were also occasional violent demonstrations led by masked youth, who employed guarimbas (barricades to close streets), among other direct tactics. These more overt strategies were complemented by the unsuccessful 2004 recall referendum to remove President Chávez from power and the opposition boycott of the 2005 regional and parliamentary elections. Although opposition strategies were characterized by moves toward electoral and programmatic unity from 2006 on, extra-institutional strategies did not go into abeyance entirely but were concentrated primarily among mass mobilizations of students, beginning with demonstrations against the closure of opposition television channel RCTV in 2007.

These demonstrations were led by student organizations, which initially claimed to be apolitical, avoiding overt identification with the opposition and abjuring violence (Brading 2012). Nevertheless, as the movement's momentum progressed, these characteristics were eclipsed by key media-promoted figures affiliated with opposition political parties and the U.S. political establishment (Brading 2012; Ciccariello-Maher 2007). ${ }^{8}$ While the main strategy consisted of peaceful demonstrations, guarimbas and other violent tactics were also used. The student movement did have considerable success in galvanizing public opinion and may well have had a bearing on one of the few electoral defeats experienced by the government in a December 2007 referendum on constitutional amendments.

This particular cycle of protests eventually lost momentum due to differences in leadership, a perceived lack of representativeness, and overt identification with 
opposition political parties. But student protests continued in 2010, again in defense of private broadcasters and against alleged government encroachment on university autonomy; in 2011 in support of opposition-linked "political prisoners"; in 2012 against underfunding in the university sector; and in 2013 against an alleged media blackout about Chávez's illness (Buxton 2014).

Such extra-institutional tactics have once again come to the fore since Hugo Chávez's death on March 5, 2013. Despite Chávez’s previous October 7, 2012 win in presidential elections by a wide 11 percent margin and polls suggesting an ample victory for Nicolás Maduro, Chávez's preferred successor, the MUD achieved a remarkable 49 percent of votes cast compared to the PSUV-led coalition's 50.8 percent, a mere 1.8 percent difference (Hellinger and Gable 2013). On the basis of such a close finish, the MUD candidate, Henrique Capriles, immediately refused to recognize the result, alleging fraud and asking for a recount of the votes "one by one," signifying a more controversial count of the paper ballots rather than the customary audit of the electronic voting machines used in Venezuelan elections (Hellinger and Gable 2013). It is notable that the MUD position was supported by the United States, which refused to recognize the Maduro government, while Brazil and many other Latin American countries immediately accepted the results (see Páez 2013).

Capriles then went on to encourage supporters to demonstrate in the streets against the alleged fraud, a call amplified in the privately owned media, recalling previous radical strategies (Hellinger and Gable 2013). This call led to eight PSUV supporters being killed, dozens reported wounded, PSUV offices being set on fire, and government representatives and staff being threatened, among other violent incidences (Hellinger and Gable 2013). Yet Hellinger and Gable report that simultaneously, key opposition advisers and spokespeople were urging a less radical stance and publicly supporting the legitimacy of the result, although alleging government advantage in pre-electoral campaigning. Possibly as a result of this more moderate approach, as well as government threats of legal retaliation toward Capriles himself for the violence, a planned mass opposition demonstration was called off (Hellinger and Gable 2013) and the street campaign effectively abandoned.

The suspicions of fraud did not prevent the opposition from participating in the following December 8, 2013 regional and local elections. Previous opposition tactics had possibly led to a surge in support for the opposition among the so-called ni-nis (non-party-affiliated voters) and dissatisfied government supporters. But now postelection violence, encouraged by more radical sectors in the opposition-specifically ex-opposition primary presidential candidates María Corina Machado and Leopoldo López (see Venezuela Soberana 2013) — may have backfired with a relatively poor performance in these elections. ${ }^{9}$ Since the December 2013 elections, reports have suggested that the Maduro-led government has radicalized even further (Meza 2014). That trend, along with severe economic problems, including high inflation and some food, consumer goods, and foreign currency shortages, may have contributed to the decision by the aforementioned radical leaders to spearhead an opposition street rebellion in early February 2014. Again, a large proportion of 
demonstrators came from student ranks, and the protests resulted in several deaths, scores injured, and hundreds arrested. ${ }^{10}$ These events, then, illustrate once again the continuing coexistence of radical and institutionalized opposition strategies in a situation of political polarization in the post-Chávez era.

\section{IMPLICATIONS FOR THEORY}

The Venezuelan opposition, therefore, based on the findings of this study, can be said to display the following characteristics, strategies, and objectives. First, in terms of characteristics, the opposition is both parliamentary and nonparliamentary, with a varying emphasis on each of these parts over time. In the first half of the Chávez period (1999-2006), the nonparliamentary elements dominated, with business groups, trade unions, the media, and parts of the military all playing a leading role and with political parties in the back seat. More recently, the parties have taken the lead, but with nonparliamentary elements still having a powerful voice in policy formation and popular mobilization.

Nevertheless, this period was also characterized by large student mobilizations, sometimes with violent outcomes, in support of opposition television channels and "free speech" and more recently aimed at the removal of the current Maduro-led government. Hence the relationship between institutionalized, party-based actors and civil society actors is dialectical rather than discrete: both have important parts to play in achieving the ultimate objective of removing the government.

Second, strategies are varied, from the parliamentary to the extraparliamentary to the illegal. Here it has been argued that such strategies should be seen as constituent parts of a wider repertoire, different parts of which may be activated according to changing circumstances and linked to wider hemispheric socioeconomic and geopolitical objectives. In practice, this means that while the parliamentary may dominate in one particular moment, the other strategies may resurface at opportune moments.

Third, the opposition's objective, generally speaking, remains to install a liberal democratic regime with a market-based economy. The evidence presented here suggests that politically, the opposition seeks a privileging of the institutional, including political parties, over the participatory elements emphasized by the current government. In terms of the economy, the emphasis is on private sector activity over public, closing down state activity in almost all sectors in which it has been developed under the PSUV government. And in terms of social provision, there is an emphasis on poverty reduction, but again with ample scope for private sector involvement and an emphasis on employment in the private economy, in order to ensure a minimal role for the state.

Nevertheless, this overall characterization needs to be qualified by two further observations. There is evidence to suggest some elements of continuity with the present policy configuration, with, for example, the maintenance of the 1999 Bolivarian Constitution, the commitment to keep the state oil company, PDVSA, in public hands, and the continuance of some of the more notable Missions, such as 
Into the Neighborhood. However, in the last two cases specifically, judging from closer reading of policy papers, these institutions may be transformed beyond recognition from their present incarnations; and with policies of decentralization, "depoliticization," and downsizing of the public sector, they may indeed lose the material gains of those who have until now been supported by them, through either benefits or jobs or both.

Overall, then, these opposition policy proposals could be summarized in development terms as a neoliberal project with a "pro-poor" emphasis, similar to postWashington Consensus policy formulations, as opposed to a "shock therapy" style of neoliberal adjustment, as advocated by more radical elements in the MUD coalition (see Payne and Phillips 2010, chap. 4). Yet this ideological underpinning of opposition policy proposals is comprehensively denied by leading political personalities in the MUD, from each of the main tendencies. Moreover, this study has highlighted proposals to naturalize this ideological intention as "common sense," with declared intentions to "depoliticize" large swaths of the state apparatus. How this would be done remains unexplained, but some evidence examined here points to possible purges of PSUV personnel in those instances and plans to inculcate liberal values among Venezuelan schoolchildren through the state education system. Additionally, qualitative empirical data presented here note varying policy emphasis from different ideological strands in the MUD on some of these issues, such as privatizations.

It may be useful here to return to Zariski's theories on legitimacy as a possible, although by no means comprehensive, explanatory factor for this ambivalent discourse and these policy changes. Using his framework (table 1), we can construct, from the accounts by Corrales and Penfold (2007), Domínguez (2011), and GarcíaGuadilla (2005), among others, corresponding "endogenous" and "exogenous" groups for each type of legitimacy for the Venezuelan institutionalized opposition. Thus, in the first case, we can identify opposition supporters, mostly in the middleand upper-class groups. ${ }^{11}$ We would also recognize business groups, presumably the more "modern" or globalized ones, if we accept and adapt Corrales and Penfold's categorization $(2007,112)$; trade unions from the previous Punto Fijo regime, grouped into the CTV; some social organizations grouped under the catch-all term civil society and dominated by middle and upper social strata (García-Guadilla 2005); sectors of the Catholic Church; the military; and most of the privately owned media. It is important to note also in this context the role of the United States as principal international sponsor of the Venezuelan opposition, providing it with crucial financial, strategic, and moral backing (see, e.g., Pearson 2011; Robertson 2012; Weisbrot 2013). Here the "internal game" is to convince these groups that liberal democracy and "free market" conditions will be (re)established.

In the second "exogenous" case, we can identify "ambivalent" voters, the socalled ni-nis, in that they are with neither the government nor the opposition (Corrales and Penfold 2007). Logically we could also include some government supporters, necessary to gain an overall electoral majority; some of the business elites with closer ties to the government (so-called boliburguesía because they owe their fortunes to the current regime); the bulk of the military, one of the major lynchpins of the 
Table 2. Venezuelan Opposition's Legitimacy Matrix

\begin{tabular}{|c|c|c|}
\hline & Internal Game & External Game \\
\hline Actors & $\begin{array}{l}\text { Opposition supporters, mostly in } \\
\text { the middle- and upper-class groups } \\
\text { More "modern" or "globalized" } \\
\text { business groups } \\
\text { Punto Fijo-era trade unions } \\
\text { grouped into the CTV } \\
\text { Opposition civil society, dominated } \\
\text { by middle and upper social strata } \\
\text { Main sectors of the Catholic Church, } \\
\text { some of the military, and most of the } \\
\text { private media } \\
\text { The United States }\end{array}$ & $\begin{array}{l}\text { Ni-nis and government } \\
\text { supporters, necessary to gain an } \\
\text { overall majority } \\
\text { Business elites with closer ties to } \\
\text { the government (boliburguesia) } \\
\text { Bulk of the military } \\
\text { Allied Latin American } \\
\text { governments, particularly those } \\
\text { grouped in Mercosur, and } \\
\text { especially Brazil }\end{array}$ \\
\hline Objectives & $\begin{array}{l}\text { (Re)establishment of a liberal } \\
\text { democratic and "free market" regime }\end{array}$ & $\begin{array}{l}\text { Continued respect for and } \\
\text { maintenance of elements of } \\
\text { existing institutionality }\end{array}$ \\
\hline
\end{tabular}

Source: Author's elaboration, based on Zariski 1986 and drawn from Corrales and Penfold 2007; Domínguez 2011; and García-Guadilla 2005, among others

Bolivarian regime (Corrales and Penfold 2007); and crucially, other Latin American governments, particularly those grouped in Mercosur, and especially Brazil, as the major power in that group and in the South American region. Here the "external game" is to convince these groups that basic institutionality or gains under the present regime will be respected at some level. These groupings are illustrated more graphically in table 2 .

Finally, in terms of objectives, these can be modified as a result of the first two factors; objectives and strategic direction can be adjusted as the impact on legitimacy, both endogenous and exogenous, is evaluated.

Examining all this evidence, we can construct a plausible hypothesis for strategic and policy adaptation based on this theory. At the "endogenous" level, with regard to opposition supporters, previous insurrectionary strategies failed to achieve their principal objective: the removal of Chávez from power. First, the 2002 coup prompted serious evaluations of tactics, and some opposition actors rejected the abolition of institutional structures by the brief government of business leader Pedro Carmona Estanga (Poleo 2002).

Second, each government win seemed to lead to policy radicalization on its part, making the situation more difficult for the opposition and its supporters (Corrales and Penfold 2007). Third, radical strategies had a counterproductive effect on Venezuelan society in general and on the opposition's main constituency in particular (García-Guadilla 2005). ${ }^{12}$ Fourth, the intense mobilization needed for such strategies must have taken its toll in terms of energy and commitment for those who 
participated, reducing motivation for future efforts. Hence, such strategies were causing a crisis for the opposition's "endogenous legitimacy" both by failing in its main objective of removing Chávez and by trying the patience of the opposition's own supporters. The cost of these extraparliamentary and illegal strategies and the huge cost to "endogenous" groups may have prompted a reorientation in political strategy toward more constitutional tactics.

On a policy level, additionally, assurances of the installation of liberal democracy and "professionalization" of social policy with possible returns of these groups to stewardship of the main bureaucracies satisfy key demands for "endogenous" middle- and upper-class groups. These proposals, and those promising wider macroeconomic restructuring and geopolitical realignment, would also help satisfy demands from the opposition's principal international sponsor, the United States.

At an "exogenous" level, in opinion polls, a large majority of Venezuelans repeatedly have expressed their adherence to democratic values (see, e.g., Batista Pereira et al. 2013). This would suggest a low tolerance level among a majority of Venezuelans-including government supporters and the so-called ni-nis—-for extraconstitutional power strategies. Furthermore, the increasing moves in the South American region toward greater union, especially with the foundation and consolidation of UNASUR, have meant less tolerance for extraconstitutional strategies to gain power and for U.S. interference in the region's internal affairs. This would suggest that the Venezuelan opposition must also take its closest neighbor's opinions into account when designing its power strategies. At a policy level, promises to maintain the popular Missions (Young and Franco 2013) and to keep PDVSA in state hands will help assure "exogenous" legitimacy from ni-nis and disillusioned government supporters, increasing the opposition's electoral chances. And the overall emphasis on constitutional paths to power may help assuage the doubts of leading powers in the more immediate region, most notably those grouped into Mercosur, and particularly Brazil.

Nevertheless, in the 13 years since Chávez first came to power and even since his death, the opposition has failed to win national political power through the electoral route. In addition, many of the more radical sectors are firmly convinced that under the existing Bolivarian institutional configuration such an opposition win is simply impossible, due to suspicion of fraud and other concerns. This reading of events could possibly explain the salience given by sectors of the opposition to extraconstitutional strategies from 2013-14 (Arria 2013; Venezuela Soberana 2013; Brown 2013), especially as these have received the firm backing of the United States and the international media (Buxton 2014).

In sum, following Brack and Weinblum (2011), such changes may be best seen not as dichotomic, discrete, or linear strategic directions, but instead as parts of a wide repertoire, different parts of which may be activated according to changing circumstances. Electoral strategies can also lose legitimacy if they are not successful, and as we have seen, more radical elements in the opposition, both domestic and international, are still pressing for strategic radicalization, which goes beyond the electoral. Furthermore, these latter extraconstitutional strategies may fit into a wider regional 
strategy on the part of the right, backed by radical elements in the U.S. institutional apparatus (Romano and Delgado Ramos 2012). Therefore, promises of widespread privatizations and increased market dominance go some way to assuage these sectors while giving them the opportunity to press for more strategic advantage.

While this article concentrates on the Venezuelan case, it also throws light on a theory of opposition that would be of use beyond Venezuela. It highlights two main points in terms of opposition characterization, discourse, and strategies, respectively. In terms of characterization, it illustrates the need for a wider definition of opposition that goes beyond political parties, as recommended by Brack and Weinblum (2011), to include a wide variety of different types of social organizations. The roles and salience of the distinct actors may face adjustment over time, but their relevance still needs to be recognized and evaluated to gain a more comprehensive picture of opposition(s) in their fullest sense.

In terms of discourse and strategies, the Venezuelan case shows that these can go beyond the parliamentary to include all manner of extraparliamentary acts, and they need to be analyzed together as part of one overall strategy. Again, emphasis in discourse and on different types of strategic components may change along with circumstances, but all such actions and strategies need to be kept in mind as opposition activity is assessed.

In these ways, Venezuela presents a vigorous challenge to more orthodox, institutionalized interpretations of opposition politics, one that has resonance beyond the country's borders, particularly in Latin America. Eaton (2013), for example, points to the importance of social mobilization in successful opposition strategies in support of decentralization in Bolivia. Fairfield (2011) cites business protest in opposition politics in Argentina against President Cristina Fernandéz de Kirchner, using the 2008 agricultural producers' protests as a case study. Protests in Chile among students between 2006 and 2013 (Jara Reyes 2012) and in Brazil against the Workers' Party government led by Dilma Rousseff in 2013 (Saad Filho 2013) underline again the centrality of noninstitutionalized processes in oppositional politics. All of these examples point to the need for a more comprehensive and flexible approach to the study of opposition, as used in this article, that considers both institutional and noninstitutional actors and strategies, privileging neither, in one overall theoretical framework.

\section{NoTES}

This article would not have been possible without the research support of Ybiskay González Torres, doctoral candidate, University of Newcastle, Australia. Ms. González Torres arranged and participated in all interviews cited here. The paper was first presented at the Latin American Studies Association 2013 Annual Congress in Washington, DC. Thanks to participants who commented on the paper at the panel on the Venezuelan elections I coconvened with Dan Hellinger of Webster University, especially to Ińaki Zagarzazu of the University of Glasgow, who acted as discussant. Special thanks again to Dan Hellinger who commented on later drafts of this paper, including suggesting using tables to help clarify concepts of endogenous and exogenous legitimacy. 
1. Henceforth referred to simply as the Lineamientos.

2. A mix of proportional representation and a nominal representation system, with a prominence of the latter over the former.

3. Four Enabling Laws were ratified while Chávez was in office, in 1999, 2000, 2007, and 2010. Despite a reduced majority, the PSUV succeeded in the National Assembly in passing President Maduro's first Enabling Law on November 19, 2013.

4. Although some dispute the "exemplary" description. See Pearson 2012.

5. All translations are the author's own. Relevant sections from interview transcripts in Spanish are available on request.

6. This institution was normally presided over by the vice president and composed of governors from each region, representatives from the National Assembly and the Supreme Court, and appointees of the president.

7. "Look again at" could also mean "change," due to the multiple translations of the Spanish word revisar. My thanks to an anonymous reviewer for pointing this out.

8. For example, Yon Goicoechea, affiliated with the First Justice Party, received a US\$500,000 Milton Friedman Prize for Advancing Liberty (Brading 2012, 135).

9. The ruling party gained 49 percent of the vote, as opposed to the MUD's 43 percent (Trinkunas 2013).

10. For information and commentary on these events and others in Venezuela, see the blog Venezuelan Policy and Human Rights, moderated by Professor David Smilde and hosted by the Washington Office on Latin America (WOLA n.d.).

11. These would number at least about three million, judging by the turnout for the opposition primaries in February 2012.

12. The business strike in late 2002 and early 2003, for example, resulted in a profound economic slump: the country lost, according to official figures, "7.6 percent of GDP, equivalent to 7.367 millon dollars" (Asamblea Nacional, Oficina de Asesoría Económica y Financiera 2003, 3).

\section{AUTHOR INTERVIEWS}

Abdul, Roberto. 2012. Director, Súmate, Caracas. Caracas, February 15. Borges, Julio. 2012. Leader, First Justice Party. Caracas, February 28.

García, Ismael. 2012. Leader, PODEMOS Party. Caracas, Februrary, 28.

Guijarro, Rocío. 2012. Director, CEDICE. Caracas, February 8.

Machado, María Corina. 2012. Independent Public Representative, Caracas. Caracas, February 17.

\section{REFERENCES}

Arria, Diego. 2013. An Open Letter to Henrique Capriles. Huffington Post/The Blog, March 19. http://www.huffingtonpost.com/diego-arria/an-open-letter-to-henriqu_b_28862 18.html. Accessed June 21, 2013.

Asamblea Nacional. Oficina de Asesoría Económica y Financiera. 2003. Impacto de la huelga general sobre las perspectivas económicas y fiscales para 2003 en Venezuela. Caracas: Asamblea Nacional.

Batista Pereira, Frederico, Mitchell Seligson, and Elizabeth J. Zechmeister. 2013. Public Support for Democracy Endures in Venezuela. AmericasBarometer: Topical Brief, March 11. http://www.vanderbilt.edu/lapop/insights/ITB002en.pdf. Accessed June 21, 2013. 
Blondel, Jean. 1997. Political Opposition in the Contemporary World. Government and Opposition 32, 4: 462-86.

Brack, Nathalie, and Sharon Weinblum. 2011. Political Opposition: Toward a Renewed Research Agenda. Interdisciplinary Political Studies 1, 1: 69-78.

Brading, Ryan. 2012. The Anti-Bolivarian Student Movement: New Social Actors Challenge the Advancement of Venezuela's Bolivarian Socialism. Asian Journal of Latin American Studies 25, 3: 23-46.

Brown. Lee, 2013. Exposing the Venezuelan Right-Wing's Attempts to Discredit April's Presidential Election. Venezuelanalysis, March 25. http://venezuelanalysis.com/analysis/ 8365. Accessed June 21, 2013.

Buxton, Julia. 2014. Venezuela: The Real Significance of the Student Protests. Latin America Bureau, February 20. www.lab.org.uk. Accessed February 27, 2014.

Cannon, Barry. 2009. Hugo Chávez and the Bolivarian Revolution: Populism and Democracy in a Globalised Age. Manchester: Manchester University Press.

Ciccariello-Maher, George. 2007. Behind Venezuela's "Student Rebellion”: Who's Pulling the Strings? Counterpunch, June 9-11. http://www.counterpunch.org/2007/06/09/ behind-venezuela-s-quot-student-rebellion-quot. Accessed May 8, 2013.

Coronil, Fernando, and Julie Skurski. 1991. Dismembering and Remembering the Nation: The Semantics of Political Violence in Venezuela. Comparative Studies in Society and History 33, 2: 288-37.

Corrales, Javier, and Michael Penfold. 2007. Venezuela: Crowding Out the Opposition. Journal of Democracy 18, 2: 100-113.

Domínguez, Francisco. 2011. Venezuela’s Opposition: Desperately Seeking to Overthrow Chávez. In Right-wing Politics in the New Latin America: Reaction and Revolt, ed. Domínguez, Geraldine Lievesley, and Steve Ludlum. London: Zed. 113-30.

Eaton, Kent. 2013. Recentralization and the Left Turn in Latin America: Diverging Outcomes in Bolivia, Ecuador, and Venezuela. Comparative Political Studies 7 (July 2014). DOI: 10.1177/0010414013488562. cps.sagepub.com. Accessed January 8, 2014. $1130-57$.

Ellner, Steve. 2008. Rethinking Venezuelan Politics: Class, Conflict, and the Chávez Phenomenon. Boulder: Lynne Rienner.

Fairfield, Tasha. 2011. Business Power and Protest: Argentina's Agricultural Producers Protest in Comparative Perspective. Studies in Comparative International Development 46, 4: 424-53.

García-Guadilla, María Pilar. 2005. The Democratization of Democracy and Social Organizations of the Opposition: Theoretical Certainties, Myths, and Praxis. Latin American Perspectives 32, 2: 109-23.

Hellinger, Daniel, and Dawn Gable 2013. Venezuela's Elections: Photo Finish and a Lingering Controversy. Caracas Connect, April. http://www.democracyinamericas.org/pdfs/ Caracas\%20Connect\%20April.pdf. Accessed August 5, 2014.

Jara Reyes, René, 2012. State-Civil Society Relations During Student Mobilisations in Chile in 2006 and 2011. In Civil Society and the State in Left-led Latin America: Challenges and Limitations to Democratization, ed. Barry Cannon and Peadar Kirby. London: Zed. 94110.

Mesa de Unidad Democrática (MUD). 2008. La alternativa para el cambio. January 23. http://www.globovision.com/news.php?nid=76943. Accessed April 4, 2012. . 2012. Lineamientos para el Programa de Gobierno de Unidad Nacional (2013-2019). January 23. http://www.unidadvenezuela.org/wp-content/uploads/2012/01/lineamien tos2012.pdf. Accessed April 4, 2012. 
Meza, Alfredo. 2014. Maduro radicaliza la revolución chavista. El País Internacional, January 6. http://internacional.elpais.com/internacional/2014/01/06/actualidad/1389034100_ 568076.html. Accessed January 6, 2014.

Norton, Phillip, 2008. Making Sense of Opposition. Journal of Legislative Studies 14, 1: 23650.

Páez, Angel. 2013. UNASUR Backs Venezuelan President Elect and Calls for Peace. Inter Press Service, April 19. http://www.ipsnews.net/2013/04/unasur-backs-venezuelanpresident-elect-and-calls-for-peace. Accessed June 21, 2013.

Payne, Anthony, and Nicola Phillips. 2010. Development. Cambridge: Polity.

Pearson, Tamara. 2011. Wikileaks Cables Reveal U.S. Embassy Works with Venezuelan Private Media. Venezuelanalysis, September 6. http://venezuelanalysis.com/news/6469. Accessed January 8, 2014.

— 2012. The Sham That Was the Opposition Primaries. Venezuelanalysis, February 15. http://venezuelanalysis.com/analysis/6811. Accessed April 4, 2012.

Poleo, Patricia. 2002. La verdadera historia de un gobierno que duró sólo horas por estar sustentado en los intereses particulares y no en los del colectivo. El Nuevo País, April 16: 3-4.

Robertson, Ewan. 2012. U.S. Policy Increasingly Out of Touch with Latin America's New Political Reality. Venezuelanalysis, April 11. http://venezuelanalysis.com/analysis/6916. Accessed July 31, 2012.

Romano, Silvina María, and Gian Carlo Delgado Ramos. 2012. Articulación de la derecha venezolana y los proyectos alternativos en América Latina. Visión Latinoamericana 4, 7: 92-117. http://www.openstarts.units.it/dspace/bitstream/10077/7296/1/Romano_ DelgadoRamos_VisioniLA_7_2012.pdf. Accessed May 7, 2013.

Saad Filho, Alfredo. 2013. The Mass Protests in Brazil in June-July, 2013. Global Research, July 15. http://www.globalresearch.ca/the-mass-protests-in-brazil-in-june-july-2013/ 5342736. Accessed January 7, 2014.

Tarrow, Sidney. 1982. Transforming Enemies into Allies: Non-ruling Communist Parties in Multiparty Coalitions. Journal of Politics 44: 924-54.

Trinkunas, Harold. 2013. The Consequences of Venezuela's December 8th Municipal Elections. Brookings UpFront, December 9. http://www.brookings.edu/blogs/up-front/ posts/2013/12/09-consequences-venezuela-municipal-elections-trinkunas. Accessed January 9, 2014.

Venezuela Soberana. 2013. Manifiesto a la sociedad democrática venezolana y a su fuerza armada nacional. Petition. GoPetition, January 9. http://www.gopetition.com/petitions/ manifiesto-a-la-sociedad-democr\%C3\%A1tica-venezolana-y-a-su.html. Accessed June $21,2013$.

Washington Office on Latin America (WOLA). n.d. Venezuelan Policy and Human Rights. Blog. http://venezuelablog.tumblr.com

Weisbrot, Mark. 2013. Obama's Latin America Policy: Continuity Without Change. Washington, DC: Center for Economic and Policy Research. http://www.cepr.net/documents/ publications/obamas-latin-america-policy-2011-05.pdf. Accessed January 8, 2014.

Young, Clifford, and Julio Franco. 2013. No Matter Who Wins in Venezuela, Chávez's Legacy is Secure. Reuters Great Debate, April 13. http://blogs.reuters.com/great-debate/ 2013/04/12/no-matter-who-wins-in-venezuela-chavezs-legacy-is-secure. Accessed June 21, 2013.

Zariski, Raphael. 1986. The Legitimacy of Opposition Parties in Democratic Political Systems: A New Use for an Old Concept. Western Political Quarterly 39, 1: 29-47. 